\title{
Growth phenology in Pinus halepensis Mill.: apical shoot bud content and shoot elongation
}

\author{
Anna Hover $^{1}$ - Fabien Buissart ${ }^{2} \cdot$ Yves Caraglio $^{1} \cdot$ Christine Heinz $^{3}$ - François Pailler ${ }^{4}$. \\ Merlin Ramel $^{4}$ • Michel Vennetier ${ }^{2}$ - Bernard Prévosto ${ }^{2} \cdot$ Sylvie Sabatier $^{1}$
}

Received: 2 December 2016/Accepted: 11 April 2017 /Published online: 3 May 2017

(C) INRA and Springer-Verlag France 2017

\begin{abstract}
- Key message The chronology of periods of organogenesis and elongation is highlighted in Pinus halepensis. The two first growth units of an annual shoot are preformed inside the bud during the previous year. The following growth units are formed during the spring or summer of the current year. - Context Analysis of annual shoot length growth phenology is crucial to assess the impact of climate change on tree production. Little is known about the basic growth characteristics and the phenology of pines.

- Aims The present study disentangles the roles of shoot organogenesis vs elongation in the annual growth cycle of the polycyclic Aleppo pine.
\end{abstract}

\footnotetext{
Handling Editor Michael TAUSZ

Contribution of the co-authors A Hover collected and analyzed the histological data, and made the photomicrographs; F Buissart, F Pailler, M Ramel, and S Sabatier collected the growth data; B Prévosto designed and ran the experiment; F Buissart, Y Caraglio, C Heinz, S Sabatier, and $M$ Vennetier designed the experimental protocol; Y Caraglio and C Heinz provided expertise on the growth and histology of pines; F Buissart, A Hover, and S Sabatier wrote the manuscript.
}

Sylvie Sabatier

sylvie-annabel.sabatier@ cirad.fr

Anna Hover

anna.hover@gmail.com

Fabien Buissart

fabien.buissart@gmail.com

Yves Caraglio

yves.caraglio@cirad.fr

Christine Heinz

christine.heinz@cirad.fr

François Pailler

francois.pailler@cirad.fr
- Methods Growth of young Pinus halepensis trees was monitored monthly for 1 year. At each monitoring date, the bud content and meristem dimensions of the main stem shoots apices were analyzed.

- Results The two first growth units of an annual shoot are preformed inside the bud during the previous year. The following growth units are formed during the spring or summer of the current year. The gap between a shoot organogenesis and its elongation may vary from 1 month, for the last growth unit, to half a year, for the first growth units.

- Conclusion Our results underline the importance of taking seasonal environmental conditions from both the previous and the current year into account, in order to study the plasticity of
Merlin Ramel

merlin.ramel@outlook.com

Michel Vennetier

michel.vennetier@irstea.fr

Bernard Prévosto

bernard.prevosto@irstea.fr

CIRAD, UMR AMAP, 34398 Montpellier, France

Irstea Aix-en-Provence, 13182 Le Tholonet, France

UM, UMR AMAP, 34398 Montpellier, France

4 INRA, UMR AMAP, 34398 Montpellier, France 
annual shoot growth and its response to climate change and variability.

Keywords Polycyclic pine $\cdot$ Shoot apical meristem $\cdot$ Annual shoot $\cdot$ Plant architecture

\section{Introduction}

The predicted responses of tree growth to climate warming are an increase for boreal and temperate species and a reduction in growth for tropical species (Way and Oren, 2010). In this context, the analysis of the growth pattern of Mediterranean species, growing in an intermediate biome, may improve our understanding of general tree growth acclimation.

The length growth of the stem is the result of two main morphogenetic processes: phytomer organogenesis and elongation (Srivastava, 2002). Most studies on temperate species report organ elongation to be delayed from its initiation. New organ primordia, named preformed organs, are built up inside the bud over a specific period of time prior to their elongation (Barthélémy and Caraglio, 2007). In some cases, the two processes follow one another without resting phase or bud formation, these organs are called neoformed. In species with rhythmic growth, the meristem alternates resting periods and periods of active shoot extension. The portion of axis extended during an uninterrupted period corresponds to the growth unit (GU, Hallé and Martin, 1968). A growth unit is easily identifiable thanks to a series of short internodes associated with scale leaves which are the organs that constitute the bud, followed by a series of long internodes associated with leaves. In temperate species, the stem portion extended over 1 year is called "annual shoot." If it comprises several growth units, the annual shoot is then called "polycyclic" (Barthélémy and Caraglio, 2007).

In woody species, studies on the chronology of growth unit organogenesis and elongation revealed three patterns: both processes occur (i) simultaneously (Camellia sinensis (L.) Kuntze, Bond, 1942; Hevea brasiliensis (Willd. Ex A. Juss.) Müll. Arg., (Hallé and Martin, 1968; Fig. 1a), (ii) more or less shifted (Populus trichocarpa Torr. \& A. Gray ex. Hook, Critchfield, 1960; Quercus robur L., Champagnat et al., 1986; Juglans regia L., Sabatier and Barthélémy 2003; Fig. 1b), or (iii) completely separated in time (Pinus resinosa Ait., Duff and Nolan, 1958; Pinus pinaster Aiton, Kremer and Roussel, 1982; Cedrus deodara (Roxb. ex. D. Don) G. Don, Pillai and Chacko, 1978; Fraxinus americana L. Gill, 1971; Fagus sylvatica L., Roloff 1987; Nothofagus dombeyi (Mirb.) Blume, (Puntieri et al. 2002; Fig. 1c).

In the Pinus genus, two main patterns of annual shoot growth have been identified: shoots in which the initiation and elongation of organs are simultaneous (i.e., neoformation), and shoots in which there is a dormant period
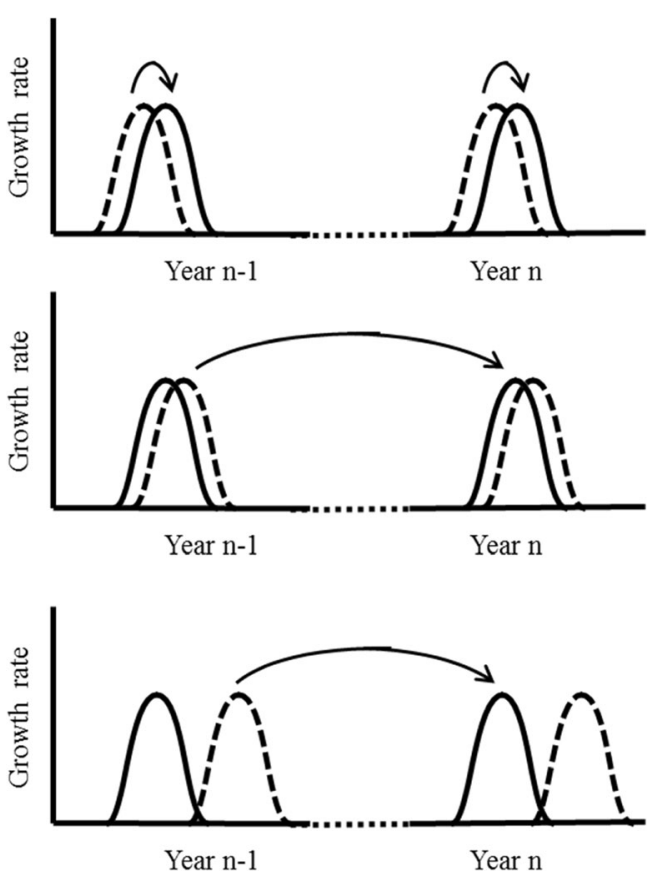

Fig. 1 Diagrammatic representation of the timing of shoot organogenesis (dotted line) and elongation (plain line). a; (above) simultaneously; b: (intermediate) organogenesis of the next shoot along with elongation of the previous one but separated from its own elongation; c: (below) completely separated in time

between the two growth events (i.e., preformation). The patterns range from entirely neoformed shoots in tropical pines, to entirely preformed shoots in northern pines (Lanner, 1976, Kremer 1981). From a morphological point of view, several successive growth units may be formed during the same annual growth period. Successive growth units produced in the same year are not identical, and each can be delimited by a series of cataphylls separated by short internodes (Barthélémy and Caraglio, 2007).

Studies on the difference in the timing of shoot development in Pinus species revealed four patterns, with a decreasing shoot growth period: (1) in tropical climates, trees grow by initiating and elongating shoots all year long, (2) in temperate climates, the formation of a winter bud resulting from an organogenetic activity from July to November, is followed by elongation of the shoot in spring and the formation and elongation of several shoots in summer, (3) the formation of the winter bud over a shorter period and elongation of the shoot in spring followed by formation and elongation of another shoot in summer, and (4) only the formation and elongation of spring shoot initiated in the winter bud (Lanner, 1976). The second and third pattern correspond to the polycyclic shoots. In several polycyclic Pinus species, the two first growth units are preformed in the winter bud (Lanner 1946, Debazac, 1968, Kremer 1981). However, studies on the chronology of shoot apical meristem (SAM) activity and shoot elongation are rare in polycyclic Pinus species. Hence, it is still not possible to accurately predict the growth response to varying climatic 
conditions. An increasingly warm and dry climate would strongly reduce the forest distribution in the Mediterranean region (IPCC 2013). Pinus species appear to be more sensitive to climate warming because of their first position in the successional process of Mediterranean forests (Carnicer et al. 2013). Pinus halepensis Mill. (Aleppo pine) is the most widely distributed pine in the Mediterranean region (Quézel 2000). Its ability to survive and grow in different environments, ranging from a meso-mediterranean to a semi-arid climate, can be explained by its ability to adapt its physiology and growing season to drought severity and variability, which implies intrinsic ecophysiological adjustments (Maseyk et al. 2008; Klein et al. 2012).

In Pinus halepensis, the two first growth units were usually distinguishable in terminal bud of shoot and a variable number of growth units elongated over summer and autumn (Pardos et al. 2003). In Pinus brutia Ten., Isik et al. (2002) concluded that the number of flushes in a year (i.e., polycyclism rate) contributes to its adaptation to a wide range of environments. In Aleppo pine, the shoot polycyclism rate varies with the prevailing climatic conditions during the growing season (Girard et al. 2011, Girard et al. 2012), the position of the axis in the crown, in terms of architecture, and the ontogenetic stage of the apical meristem (Caraglio et al. 2007; Girard et al. 2011; Vennetier et al. 2011). It also depends on genetic factors (Esteban et al. 2010, Mutke et al. 2003, Pardos et al. 2003). However, the developmental pattern of the annual shoot has been poorly studied to date.

Polycyclism can be interpreted as a key adaptation trait of Aleppo pine to a climate characterized by a high variability, particularly in the severity and length of summer drought, which cuts the growth season into two parts. For a better knowledge of the polycyclic growth and to define what would be the most sensitive period (critical stage, crucial phase) in a changing environment, we investigated the chronology of the two growth processes, organogenesis and elongation, over 1 year in an experimental plantation under a Mediterranean climate. We performed joint analysis of the content of the terminal bud and the elongation of the annual shoot over 1 year.

\section{Materials and methods}

\subsection{Sites and plant material}

The study site was an experimental stand of Aleppo pine, in an abandoned agricultural field at Barbentane $\left(43.88663^{\circ} \mathrm{N}\right.$, $4.74628^{\circ} \mathrm{E}$ ) in Southern France. The average annual rainfall is $663 \pm 72 \mathrm{~mm}$ and the annual average temperature was $14.7 \pm 0.25{ }^{\circ} \mathrm{C}$ for the period $2008-2013$. The soil was homogeneous, with a loamy-sandy texture, a low stone load and a high depth $(>1 \mathrm{~m})$, and displayed a significant level of water and fertility. In winter 2008, 1-year-old pine saplings were planted mixed with Quercus pubescens Willd. or Quercus ilex L. saplings on $2 \times 2.5 \mathrm{~m}$ plots according to an experimental design described in Prévosto et al. (2016). In March 2013, 20 plots composed of an upper layer of 15 to 25 pines per plot and an under layer of 10-12 oaks were selected. Two trees per plot were selected in the middle of the plots to avoid any edge effect, to follow the main stem shoot growth. The seven-year-old Aleppo pines had a mean height of $3.5 \mathrm{~m}$ and a mean stem base diameter of $3.7 \mathrm{~cm}$ while the oaks had a mean height of $0.83 \mathrm{~m}$ and a mean stem base diameter of $0.84 \mathrm{~cm}$. Young trees were chosen for analyze the optimal development and for monitor the growth of the main stem. We investigated the annual shoot growth of the top of the main stem using a ladder.

\subsection{Data collection}

Measurements and sampling were performed monthly from March 2013 to February 2014. Sampling consisted in collecting each month the apical bud on the main stem from ten individuals chosen randomly across the experimental site (each tree was sampled only once). At the time bud was collected, shoot lengths were measured on sampled trees for the last annual shoots. Measurements targeted growth unit length within each annual shoot for the 16 trees selected in March 2013 (Fig. 2). For each selected axis, monthly observations of the current growth unit derived from terminal bud were made over the year 2013. At the end of their elongation, the length of ten leaves per growth unit was measured.

\subsection{Histology}

At each observation date, the ten sample buds were dissected by removing the scales that protect the apical meristem under a stereomicroscope (Olympus SZX9, up to 57*). The buds without scales were then fixed in a mixture of glutaraldehyde (50\%) paraformaldehyde (20\%), and cafein (30\%). To identify meristem activity, two samples were selected randomly and cut lengthwise into 5 - $\mu \mathrm{m}$ slices using a microtome, so as to reach the most central part of the apical meristem dome.

For each observed bud (two buds * 13 observation dates), different types of embryonic organs were recorded: cataphyll primordia (CP), axillary meristem (AM), embryonic brachyblast (EB; embryonic dwarf shoot bearing two or three photosynthetic leaves in Pinus halepensis) or embryonic auxiblast (EA; embryonic long shoot, Fig. 3a). The aim of this information is to define the stage of organogenesis of the growth unit and to identify the number of growth units preformed and protected inside the bud.

\subsection{Shoot apex meristem morphometry}

Shoot activity was characterized by observing morphological traits to estimate the period of organ initiation and elongation 


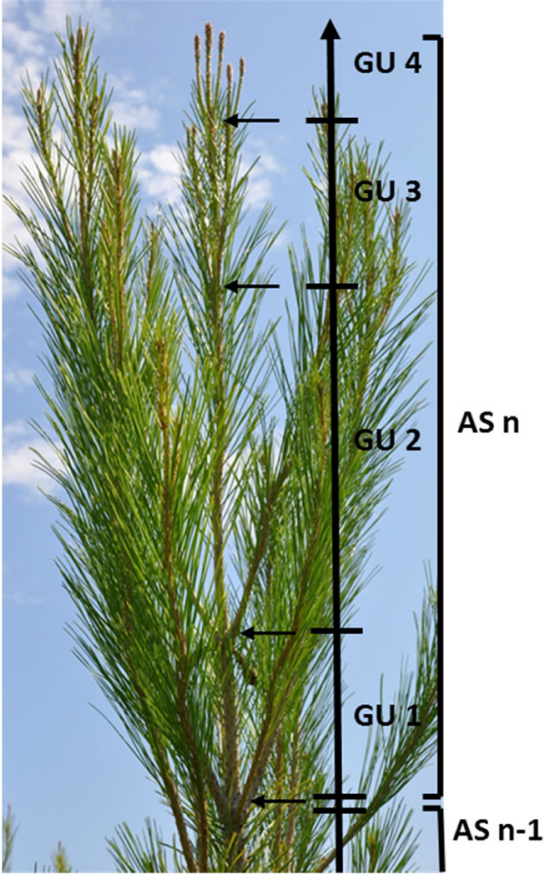

Fig. 2 Photograph and diagrammatic representation of a tetracyclic shoot in August 2014

and by measuring the size of the shoot apex meristem (Jordy, 2004). Shoot apex meristem height (H) and width (W) were measured just below the last primordia (Fig. 3 b) and just above the last primordial. As shoot apex meristem shape is similar to a cone, the equations $\mathrm{Vmax}=\mathrm{W} 1^{2} * \mathrm{H} 1$ and $\mathrm{Vmin}=\mathrm{W} 2{ }^{2} * \mathrm{H} 2$, which are proportional to the volume of a cone, were assumed to be proportional to the shoot apex meristem volume (Fig. 3). Due to the time-consuming process, as it took $8 \mathrm{~h}$ for each bud, we were able to analyze two buds per date.

\section{Results}

\subsection{Evaluation of activities within the shoot apex}

During the growing season, we observed differentiation of the organs inside the bud, presented here chronologically from the budburst in March. Cataphyll or scale leaf primordia of the third growth unit of the year appeared proximal to the shoot apex meristem simultaneously with the enlargement of embryonic auxiblasts (or long shoot) of the second growth unit in March and April. The organogenesis of the third growth unit continued in May, when axillary meristems and embryonic brachyblasts were observed. When it was observed, the cataphyll primordia of the fourth growth unit emerged in June or July, at the same time as the enlargement of embryonic auxiblasts of third growth unit. In August, the fourth growth unit was no longer observed in the bud, and newly formed
Fig. 3 Photomicrographs of a winter bud without cataphyll in a young tree. a to the left Shoot apex meristem $(S A M)$ surrounded by cataphyll primordia $(C P)$ in December, axillary meristem $(A M)$, embryonic brachyblast $(E B)$ and embryonic auxyblast $(E A)$. $\mathbf{b}$ to the right and below details of SAM: primordium $(P)$, $\mathrm{AM}$ and pith parenchyma $(P P)$; c to the right and above Morphometry of SAM, maximum length $(L 1)$, maximum width (W1), minimum length (L2) and minimum width (W2)
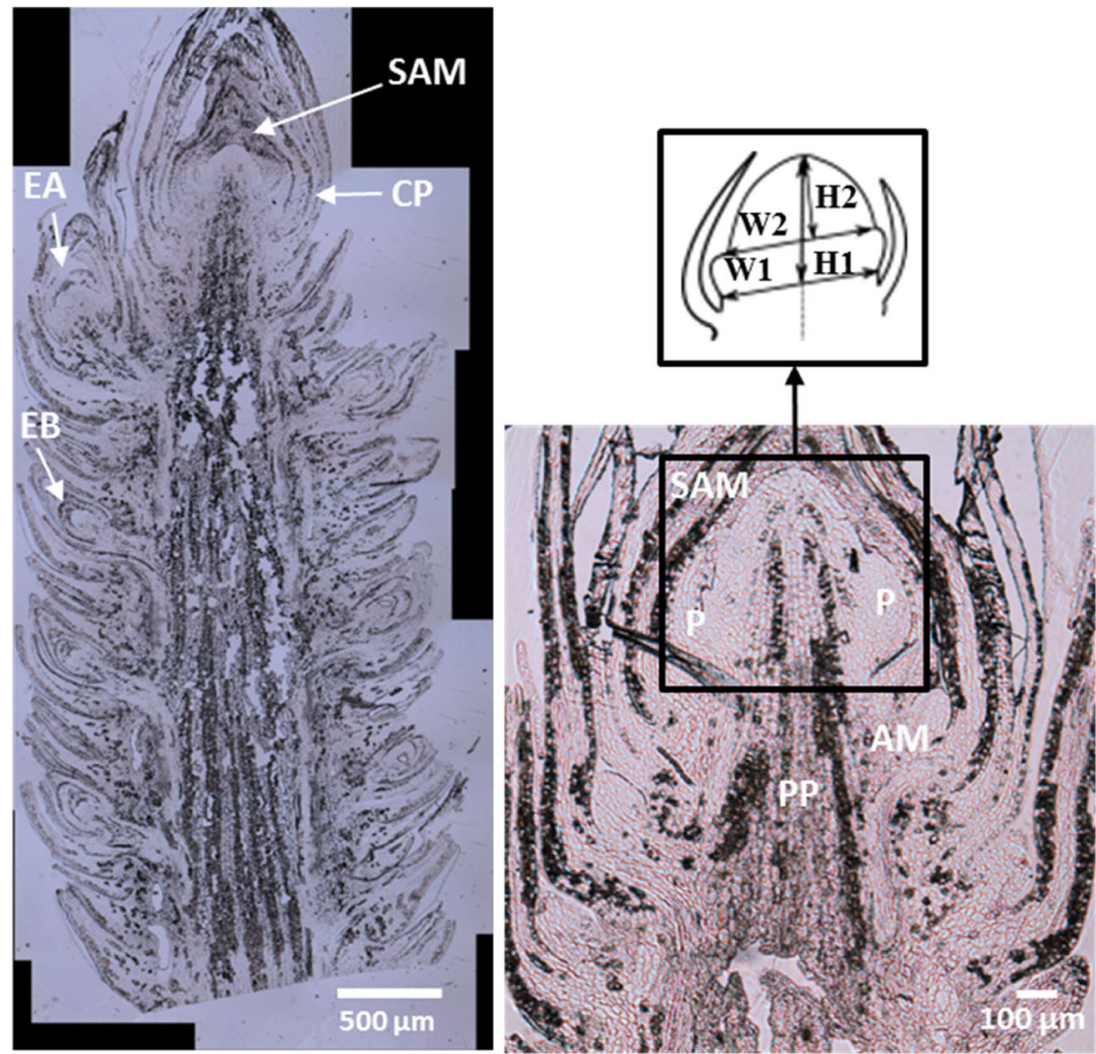
cataphyll primordia followed by the axillary meristems of the first growth unit of the next year were already visible. Embryonic brachyblasts of this future growth unit started to appear clearly in September. Cataphyll primordia of the second growth unit of the next year were formed in October or November, during the enlargement of embryonic auxiblasts of the first growth unit. From December to February, new axillary meristems appeared proximal to the shoot apex meristem on the second growth unit, while embryonic brachyblasts of second growth unit were differentiating. The cataphyll primordia of the third growth unit appeared at the end of February or beginning of March, with the development of embryonic auxiblasts of second growth unit (Fig. 4), thus ending the organogenesis cycle of the annual shoot.

During the growing season from March to October, shoot apex meristem characteristics evolved. The variations observed in shoot apex meristem volume (minimum shoot apex meristem volume and maximum shoot apex meristem volume appeared to be proportional - R2 0.75, $p<0.001$, Hover, 2014) showed an increase in meristem activity from August to October, which corresponded to the organogenesis period of the first growth unit of the next year (Fig. 5). The shoot apex meristem volume also increased slightly in April and May, which corresponds to the organogenesis of auxiblasts for second growth unit and the start of the third growth unit.

To summarize, at the monthly observation scale, the shoot apex meristem was organogenetically active over the growth season from March to October. The organogenesis of the first and second growth units of annual shoot occurred from August to September of year $n-1$ for the first growth unit, and from October year $n-1$ to February of year $n$ for the second growth unit. The period of organogenesis of the third growth unit extended from March to June and over July for the fourth one, when it occurred.

\subsection{Annual shoot elongation}

The elongation of both the first and second growth units started simultaneously in March. In general, the elongation of the third and fourth growth unit started when the previous growth unit had nearly reached its maximum growth rate (Fig. 6). The first and second growth units extended respectively from March to May and March to July. The third growth unit extended from May to August. Finally, the elongation of the fourth growth unit occurred between July and September, if at all.

\subsection{Leaf length}

The leaves of the second growth unit were longer $(8.56 \pm 1.72 \mathrm{~cm})$ than those of the first growth unit $(7.76 \pm 1.51 \mathrm{~cm})$. The leaves of the third and fourth growth units (respectively $6.39 \pm 1.83$ and $5.35 \pm 1.71 \mathrm{~cm}$ ) were shorter.

\subsection{Shoot growth phenology: shoot organogenesis and elongation}

In the winter bud, organogenesis of the first and second growth units occurred from August of year $n-1$ to March of the year $\mathrm{n}$; their elongation mainly extended from March to July. Organogenesis of the third growth unit took place in the spring bud during the elongation of the first two growth units, followed by the elongation of the third. The organogenesis of the fourth growth unit occurred in the summer bud while the third growth unit finished elongating. The last growth unit may start elongating in the same month as its initiation. The interval between the beginning of the organogenesis of a growth unit and the beginning of its elongation varied from a few days or weeks, to half a year (Fig. 7), according to the growth unit status. Indeed, this delay was about 7 months for the first two growth units whereas it was less than a month for the fourth growth unit. Since the organogenesis period is clearly distinct from the elongation period for the first two growth units, they constitute the preformed part of the annual shoot. In contrast, for the last growth units of the annual shoot, their periods of organogenesis and elongation both take place in the spring and in the summer, and they are therefore called the spring and summer preformed part of the annual shoot. That is to say, that all organs of the future elongated growth unit are present at an embryonic stage in the bud before the elongation of the growth unit deriving from it.

\section{Discussion}

\subsection{Shoot preformation and timing}

In Aleppo pine, the first and second growth unit, or spring growth units, were mainly preformed as embryonic shoots the year preceding their elongation (Pardos et al. 2003). The periods of phytomer organogenesis in the bud last from August to September for the first growth unit and from October to February for the second growth unit. This work thus suggests that the third and fourth growth units or summer growth units were preformed in the current year, respectively from March to June, and in July. While the preformation of both first growth units in a winter bud is already known, the preformation of the third and fourth growth units has never been documented. Our results show that the annual shoot of Aleppo pine consists in a portion of stem preformed in winter and a portion of stem preformed in spring or summer. The latter period also corresponds to the elongation of the shoot and brachyblasts, leading to competition for the allocation of assimilates in the plant. Moreover, the third and fourth growth 


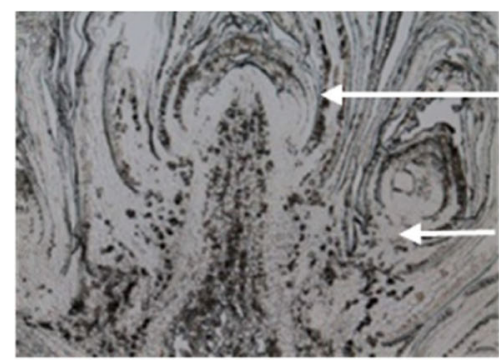

GU3-CP
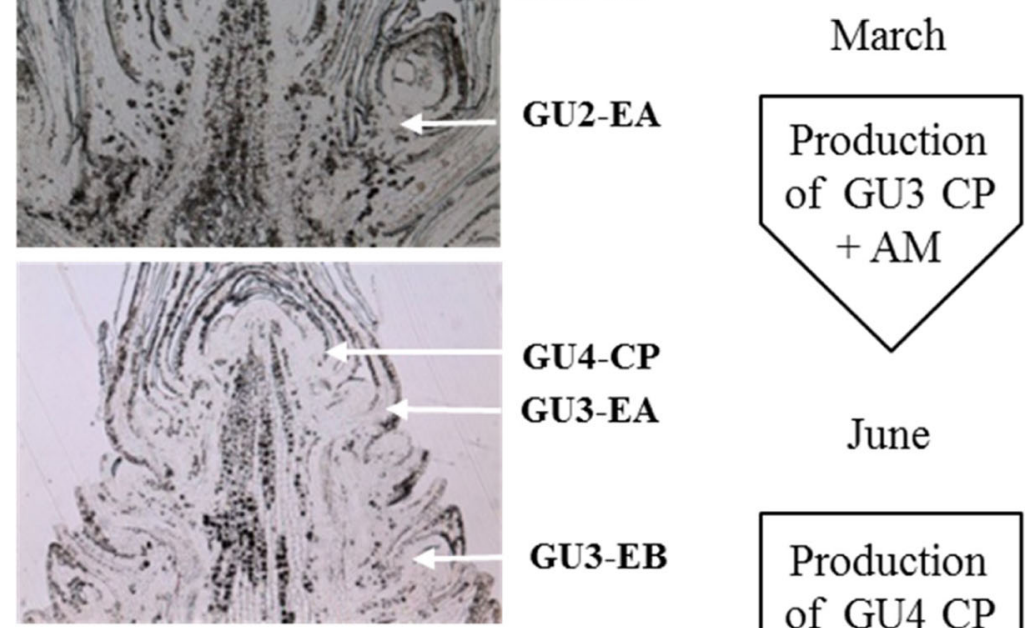

GU4-CP

GU3-EA

June

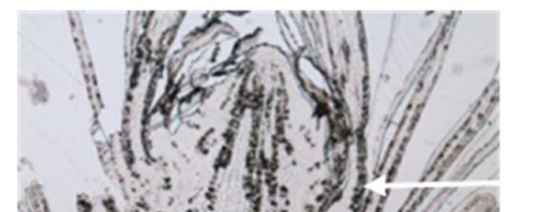

GU3-EB

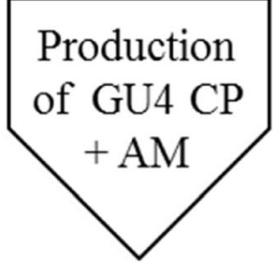

GU1-CP

August
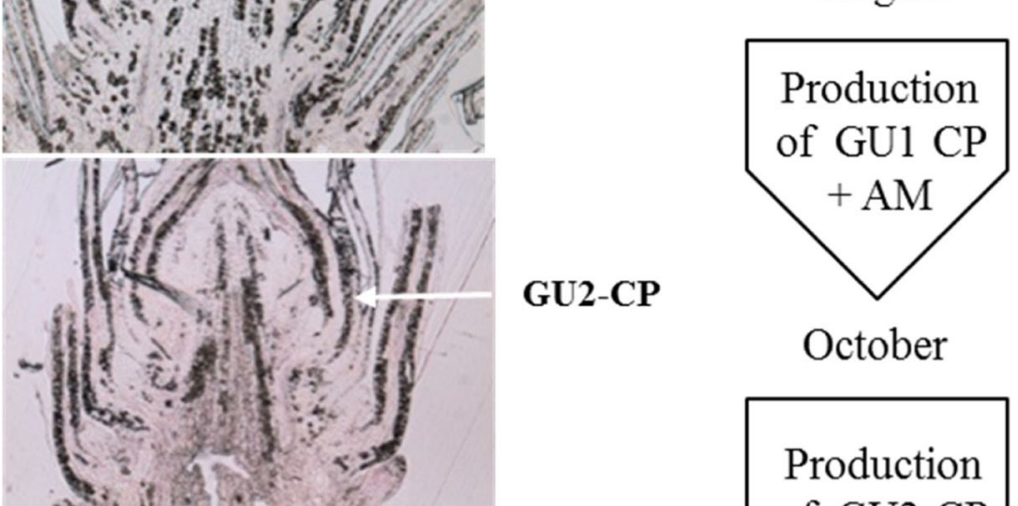

GU2-CP

October

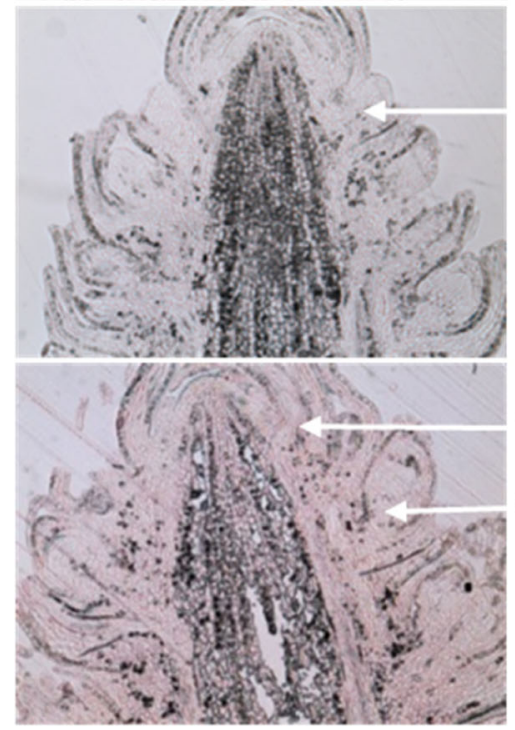

GU2-AM

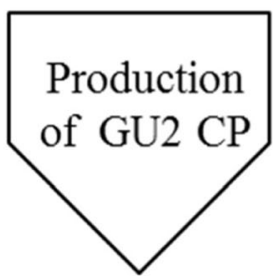

December

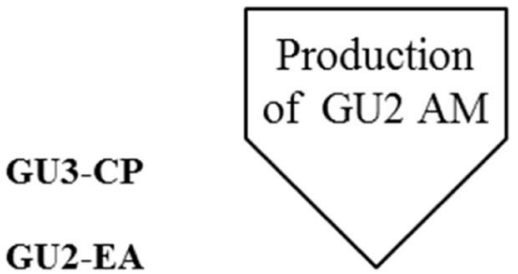

GU2-EA

February

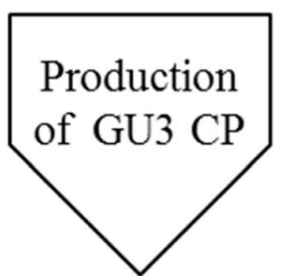


Fig. 4 Seasonal variations in bud content. Photomicrographs of the development of the bud apex at different stages of differentiation: cataphyll primordia of the third growth unit $(G U 3 C P)$ and embryonic auxyblast of the second growth unit (GU2 EA); cataphyll primordia of fourth growth uunit $(G U 4 C P$ ), embryonic auxiblast of the third growth unit $(G U 3 E A)$ and embryonic brachyblast $(G U 3 E B)$; cataphyll primordia of first growth unit (GU1 $C P$ ); axillary meristem of the second growth unit (GU2 AM); axillary meristem of the second growth unit (GU2 AM) and embryonic auxiblasts of first growth unit (GU1 EA); axillary meristem of the second growth unit $(G U 2 A M)$ and embryonic brachyblast of second growth unit $(G U 2 E B)$; cataphyll primordia of fourth growth unit $(G U 4 C P)$ and axillary meristem of the third growth unit (GU3 AM). The scale of photomicrographs is $8 \mathrm{~mm}=100 \mu \mathrm{m}$

units and their leaves are smaller than those of previous growth units. The overall results suggest not only ontogenetic controls but also environmental controls of the elongation and morphology of growth units. A study of Pinus pinea L. phenology showed that the elongation of preformed spring shoot takes place between April and June, whereas the occasional summer shoot elongated between June and August (Mutke et al., 2003). From Mutke et al. (2003), the June rainfall leads the elongation of preformed summer shoot. In Pinus nigra Arn., as the terminal bud are visible from April, April rainfall has thus an impact of the needle length of the current shoot and of the length of next annual shoot (Isik, 1990).

However, our results were obtained using young trees growing in soils that are fertile for the Mediterranean region. Thus the rate of polycyclism and the size of the annual shoot were greater than that of trees growing in the less fertile soils frequently encountered in Mediterranean forests. Hence, the analysis of the optimal development of Aleppo pine facilitated our understanding of the phenology of growth. The results concerning the spring growth units could be extrapolated to older trees and on less fertile sites, as the periods and stages of shoot growth and bud development are similar (Vennetier et al. 2011). Our results on later growth units have to be

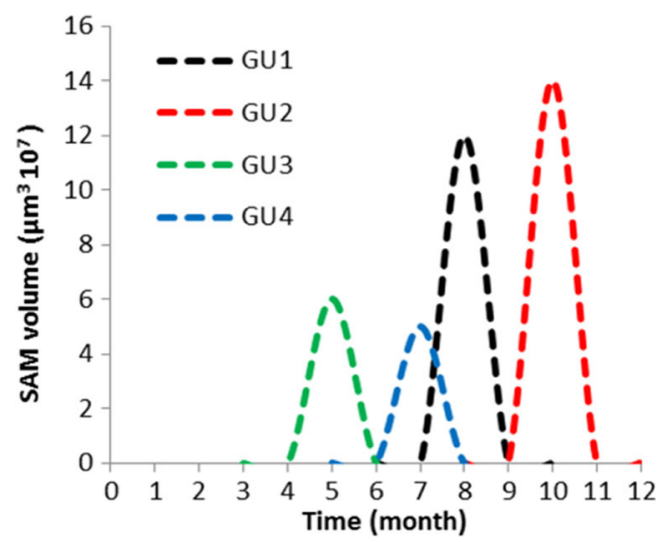

Fig. 5 Diagrammatic representation of seasonal variations in meristem volume $(\mu \mathrm{m} 3)$ in the shoot apex meristem according to the growth unit rank of the annual shoot. This representation was based on the measurement of SAM volume at monthly intervals

\section{Elongation of tricyclic ASs}

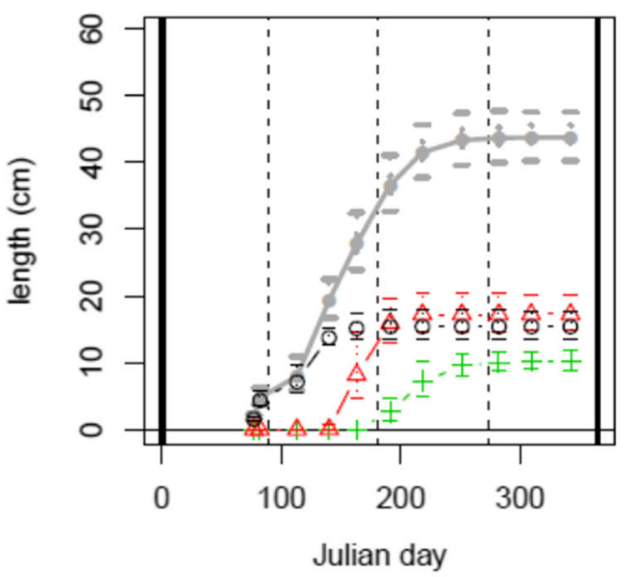

\section{Elongation of quadricyclic ASs}

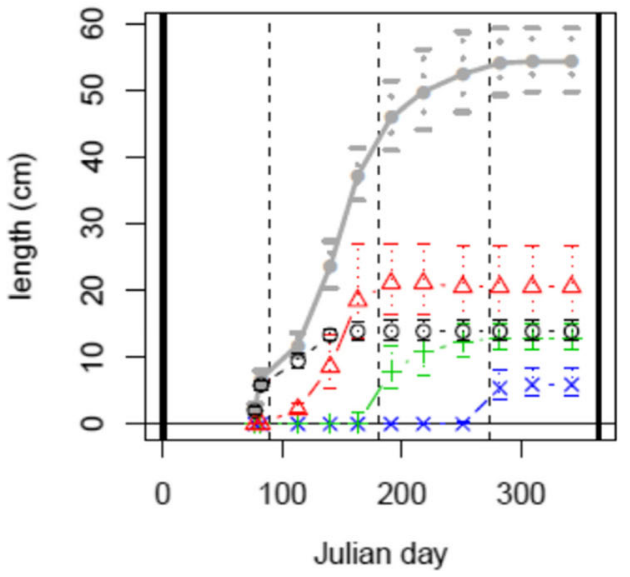

Fig. 6 Mean cumulative length and standard deviation of growth units according to their rank and mean cumulative length of annual shoot (gray line) and for tricyclic annual shoots (a) above and tetracyclic annual shoots (b) during year 2013. Each growth unit is represented by: a circle for GU1, a triangle for GU2, a straight cross for GU3 below and a cross for GU4

reconsidered in such a context, as polycyclism rate is lower (Girard et al., 2011).

In Aleppo pine, organogenesis and elongation of growth units are dissociated. This behavior makes it possible to regulate shoot growth according to the climatic conditions of the past and current year. During a bad year, and on poor sites, only two growth units may be prepared for the next year, limiting the need for resources of weak trees. The third growth unit forms in the terminal bud in spring and eventually elongates in spring and summer, or later in autumn, if the conditions are favorable. As a whole, growth units formed a given time will lengthen if local conditions are good, or wait. Thus, Aleppo pine can avoid the summer dry season and adapt to other stresses all along the year by preserving the embryonic shoot in the bud until environmental conditions become favorable. 


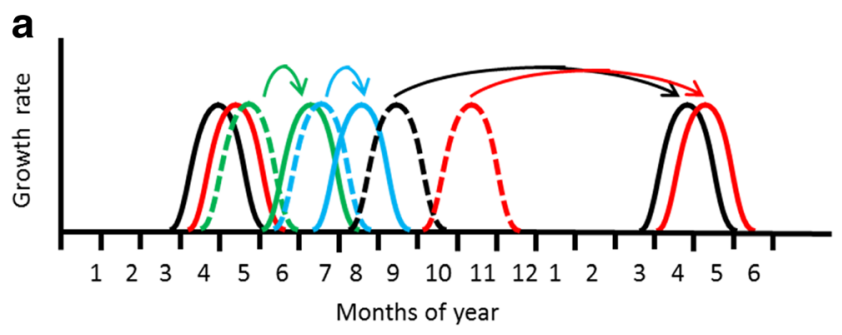

b

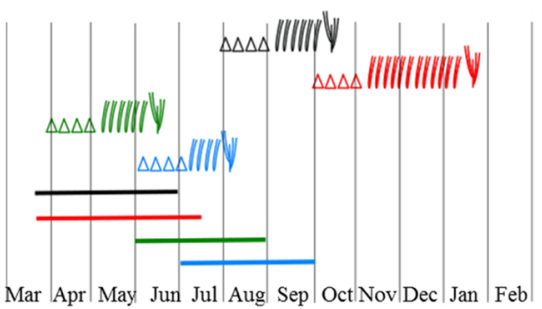

Fig. 7 Chronology of organogenesis and elongation periods of growth units (GU) of annual shoot over 1 year. a Organogenesis (dotted line) and elongation activity of each GU (solid line). b Periods of axillary productions (symbols: respectively cataphylls, brachyblasts or auxiblasts) of shoot meristem and shoot elongation (solid line) for GU1 (black), GU2 (red), GU3 (green) and GU4 (blue) during one annual growth

As discussed by Pardos et al. (2003), this behavior combines the security of spring growth units and the opportunism of a summer or autumn shoot. This growth pattern avoids activity during the severe droughts that characterize the Mediterranean climate. In Turkish pine, whose growth pattern is similar to that of Aleppo pine, the number of summer growth units varied according to the origin of the population: a population growing in the middle of the species' altitudinal range had a higher number of summer growth units than a population growing at either a lower or a higher elevation (Isik et al. 2002). This behavior suggests efficient adaptation of growth to environmental constraints. As in Cedrus species, polycyclism is an adaptive trait to drought conditions (Sabatier et al., 2003). This high plasticity to drought conditions may be responsible for the abundance of Aleppo pine in the Mediterranean region.

\subsection{Shoot apical meristem size and pith size}

The volume of shoot apex meristem tended to show four peaks over the growing season. Recent results on Pinus brutia and $P$. halepensis, species of the halepensis group, showed that pith size decreases from the first to the last growth unit along the annual shoot, and that the pith of the first growth unit is thicker than that of the third and fourth growth unit (Buissart et al., 2015). The pith tissue derives from shoot apex unit and thus reflects primary meristem activity (Longuetaud and Caraglio, 2009). Our results suggest a link between the variation in the pith size of a growth unit and its organogenesis periods. The variation in pith size resulting from meristem activity confirms that the properties of the meristem vary over the growing season. This change should reflect both the ontogenetic development and climate factors. Studies of growth with a focus on the pith conducted at experimental sites with rain exclusion would be useful to assess the effect of drought on annual shoot organogenesis.

\subsection{In the context of climate warming}

Our results showed that the organogenesis of a portion of the annual shoot is achieved during the previous year, and another portion in the current year, simultaneously with shoot elongation. Consequently, growth climate models should take into account the effects of climate factors in both the previous and current years, on shoot organogenesis and elongation. This concept has already been integrated in Markov switching models (Chaubert-Pereira et al., 2009) and applied to the walnut tree (Taugourdeau et al., 2011). In some northern conifer species, the climatic factors of the previous and current years have also been integrated in statistical models of tree growth (Buissart, 2015).

The impact of climatic factors on tree development can be analyzed using the phenology of leaves, flowers, or budburst. In recent studies, spring phenophases have been modeled using a process-based model which takes into account year $\mathrm{n}$ -1 through the three phases of bud dormancy (for a review, see Delpierre et al. 2016).

To date, the impact of climate warming on the length of the growing season raises questions about the determinism of bud dormancy and budburst (Primack et al., 2015). In particular, the role of temperature and of the photoperiod in the regulation of bud dormancy has still not been disentangled. Tree phenology models need to consider the ontogenetic programme of development from bud initiation to leaf senescence or fruit ripening (Delpierre et al., 2016). The growth pattern of Pinus halepensis, with a long growth period and several growth flushes, may be a good model to improve our knowledge of tree phenology and bud dormancy.

\section{Conclusion}

From these first results, we propose an overall chronology of organogenesis and elongation phases for an annual shoot. However, to pinpoint their development cycle, particularly the periods of the reproductive induction, it will be necessary to analyze a larger number of terminal buds. Fluctuations in climate affect all tree organs, even the cambium and root meristems. In polycyclic pines, the coordination between primary and secondary growth is not yet resolved. Further work is required to obtain the coordination of the stem and root length growth together with radial growth. 
Acknowledgements We thank JL Verdeil and F Montes for help with histological work, and M Lartaud for computer plugins in ImageJ software (PHIV, CIRAD, Montpellier)

Funding This work was supported by funds from the "Adaptation of agriculture and forests to climate change, Assessing of the potential of forest adaptation to climate change project" (INRA-ACCAF FORADAPT Project), from the Botany and Computational Plant Architecture joint research unit (UMR AMAP), from the National Research Institute of Science and Technology for Environment and Agriculture (Irstea) and the Provence-Alpes-Côte d'Azur region (F Buissart's PHD grant).

\section{References}

Barthélémy D, Caraglio Y (2007) Plant architecture: a dynamic, multilevel and comprehensive approach to plant form, structure and ontogeny. Ann Bot 99:375-407

Bond TET (1942) Studies in the vegetative growth and anatomy of the tea plant (Camellia thea link.) with special reference to the phloem. I. The flush shoot. Ann Bot 9:183-216

Buissart F, Caraglio Y, Borianne P, Guéroult M, Le Bec J, Pailler F, Vennetier M, Zilliox C, Sabatier SA (2015) Pith: a new criterion for monitoring the architecture in Mediterranean pines. Trees 29: $1827-1836$

Buissart F (2015) Modélisation des effets directs et différés du changement climatique sur le développement architectural des résineux. $\mathrm{PhD}$ thesis, Aix Marseille Université, France

Caraglio Y, Pimont F, Rigolot E (2007) Pinus halepensis Mill. Architectural analysis for fuel modelling. Proc Int Workshop MEDPINE:43-59

Carnicer J, Barbeta A, Sperlich D, Coll M, Penuelas J (2013) Contrasting trait syndromes in angiosmerms and conifers are associated with different responses of tree growth to temperature on a large scale. Front Plant Sci 4:1-19

Chaubert-Pereira F, Caraglio Y, Lavergne C, Guedon Y (2009) Identifying ontogenetic, environmental and individual components of forest tree growth. Ann Bot 104:883-896

Critchfield WD (1960) Leaf dimorphism in Populus trichocarpa. Am J Bot 47:699-711

Debazac EF (1968) Les modalités de la croissance en longueur chez les Pins. In: Colloque sur la physiologie de l'arbre, 1966. Mémoire de la Société botanique de France, 3-14

Delpierre N, Vitasse Y, Chuine I, Guillemot J, Bazot S, Rutishauser T, Rathgeber CBK (2016) Temperate and boreal forest tree phenology: from organ-scale processes to terrestrial ecosystem models. Ann For Sci 73:5-25

Duff GH, Nolan NJ (1958) Growth and morphogenesis in the Canadian forest species. III. The time scale of morphogenesis at the stem apex of Pinus resinosa Ait. Can J Bot 36:687-706

Esteban LG, Martin JA, De Palacios P, Fernandez FG, Lopez R (2010) Adaptive anatomy of Pinus halepensis trees from different Mediterranean environments in Spain. Trees 24:19-30. doi:10. 1007/s00468-009-0375-3

Gill AM (1971) The formation, growth and fate of buds of Fraxinus americana L. in Central Massachusetts. Harvard Forestry Papers 20:1-16

Girard F, Vennetier M, Ouarmim S, Caraglio Y, Misson L (2011) Polycyclism, a fundamental tree growth process, decline with recent climate change: the example of Pinus halepensis Mill. In Mediterranean France. Trees 25:311-322. doi:10.1007/s00468010-0507-9

Girard F, Vennetier M, Guibal F, Corona C, Ouarmim S, Herrero A (2012) Pinus halepensis Mill. Crown development and fruiting declined with repeated drought in Mediterranean France. Eur J For Res 131:919-931. doi:10.1007/s10342-011-0565-6

Hallé F, Martin R (1968) Etude de la croissance rythmique chez l'Hévéa (Hevea brasiliensis Müll. Arg., Euphorbiacées-Crotonoïdées). Adansonia 8:475-504

Hover A (2014) Croissance et climat: Phénologie de la croissance de la pousse annuelle polycyclique chez le Pin d'Alep (Pinus halepensis Mill., 1768). Master, AgroParisTech, Nancy

IPCC (2013) Climate change 2013 : the physical science basis in contribution of working group I to the fifth assessment report of the intergovernmental panel of climate change. Cambridge University Press, New York

Isik K (1990) Seasonal course of height and needle growth in Pinus nigra grown in summer-dry central Anatolia. For Ecol Manag 35:261-270

Isik F, Isik K, Yildirim T, Li B (2002) Annual shoot growth components related to growth of Pinus brutia. Tree Physiol 22:51-58

Jordy M-N (2004) Seasonal variation of organogenetic activity and reserves allocation in the shoot apex of Pinus pinaster Ait. Ann Bot 93:25-37. doi:10.1093/aob/mch005

Klein T, Di Matteo G, Rotenberg E, Cohen S, Yakir D (2012) Differential ecophysiological response of a major Mediterranean pine species across a climatic gradient. Tree Physiol 33:26-36

Kremer A (1981) Déterminisme génétique de la croissance en hauteur du Pin maritime (Pinus pinaster Ait.) Ann For Sci 38:199-122

Kremer A, Roussel A (1982) Composantes de la croissance en hauteur chez le Pin maritime (Pinus pinaster Ait.) Ann For Sci 39(1):77-98

Lanner RM (1976) Patterns of shoot development in Pinus and their relationship to growth potential. In: Cannell MGR, Last ST (eds) Tree physiology and yield improvement. Academic Press, New York, pp 223-243

Longuetaud F, Caraglio Y (2009) Pith: a marker of primary growth in Picea abies (L.) karst. Trees 23:325-334

Maseyk KS, Lin T, Rotenberg E, Grünzweig JM, Schwartz A, Yakir D (2008) Physiology-phenology interactions in a productive semi-arid pine forest. New Phytol 178:603-616

Mutke S, Gordo FJ, Climent JM, Gil L (2003) Shoot growth and phenology modelling of grafted stone pine (Pinus pinea L.) in inner Spain. Ann For Sci 60:527-537

Pardos M, Climent J, Gil L, Pardos JA (2003) Shoot growth components and flowering phenology in grafted Pinus halepensis Mill. Trees 17(5):442-450. doi:10.1007/s00468-003-0259-x

Pillai SK, Chacko B (1978) Anatomical and histochemical studies of the shoot apex of Cedrus deodara. Phytomorphology 28(3):275-283

Prévosto B, Gavinet J, Monnier Y, Corbani A, Fernandez C (2016) Influence of neighbouring woody treatment on Mediterranean oak development in an experimental plantation: better form but weaker growth. For Ecol Manag 362:89-98

Primack RB, Laube J, Gallinat AS, Menzel A (2015) From observations to experiments in phenology research: investigating climate change impacts on trees and shrubs using dormant twigs. Ann Bot 116(6): 889-897. doi:10.1093/aob/mcv032

Puntieri JG, Barthélémy D, Mazzini C, Brion C (2002) Periods of organogenesis in shoots of Nothofagus dombeyi (Mirb.) Oersted (Nothofagaceae). Ann Bot 89:115-124

Quézel P (2000) Taxonomy and biogeography of Méditerranean pines (Pinus halepensis and P. brutia). In: Ne'eman G, Trabaud L (eds) Ecology and biogeography and management of $P$. halepensis and P. brutia Forest ecosystems in the Mediterranean Basin. Backhuys Publishers, Leiden, pp 1-12

Roloff A (1987) Morphologie der Kronenentwicklung von Fagus sylvatica L. (Rotbuche) unter besonderer Berücksichtigung neuartiger Veränderungen. I. Morphogenetischer Zyklus, Anomalien infolge Prolepsis und Blattfall. Flora 179:355-378

Sabatier S, Barthélémy D (2003) Periods of organogenesis in mono- and bicyclic annual shoot of Juglans regia L. (Juglandaceae). Ann Bot 92:231-238 
Srivastava LM (2002) Plant growth and development: hormones and environment. Academic Press, Amsterdam

Taugourdeau O, Chaubert-Pereira F, Sabatier S, Guédon Y (2011)

Deciphering the development plasticity of walnut saplings in relation to climatic factors and light environment. J Exp Bot 62:52835296
Vennetier M, Girard F, Didier C, Ouarmim S, Ripert C, Misson L, Martin W (2011) Adaptation phénologique du pin d'Alep au changement climatique. Forêt Méditerranéenne XXXII(2): 151-166

Way DA, Oren R (2010) Differential responses to changes in growth temperature between trees from different functional groups and biomes: review and synthesis of data. Tree Physiol 30:669-688 